\title{
Active Role of Water in Hydration of Macromolecules with Ionic End Group for Hydrophobic Effect-Caused Assembly
}

(Supporting Information)

\author{
Huiwen $\mathrm{He}^{\dagger \S \|}$, Zhen Liu ${ }^{\ddagger}$, Si Chen ${ }^{\dagger}$, Xiaohua He ${ }^{*^{*}}$, Xu Wang ${ }^{\dagger *}$, Xiaosong Wang ${ }^{{ }^{*}}$
}

${ }^{\dagger}$ College of Materials Science and Engineering, Zhejiang University of Technology, 18 Chaowang Road, Hangzhou 310014, China.

${ }^{\sharp}$ School of Chemistry and Molecular Engineering, East China Normal University, 500 Dongchuan Road, Shanghai 200241, China.

${ }^{\S}$ Department of Chemistry, Waterloo Institute for Nanotechnology, University of Waterloo, Waterloo, ON, N2L 3G1, Canada.

"These authors contributed equally to this work.

*To whom correspondence should be addressed: xiaosong.wang@uwaterloo.ca.

\section{Materials and methods}

Materials. All chemicals were used as received unless otherwise indicated. Tetrabutylammonium tetrafluoroborate $\left(\left(\mathrm{CH}_{3} \mathrm{CH}_{2} \mathrm{CH}_{2} \mathrm{CH}_{2}\right)_{4} \mathrm{~N}\left(\mathrm{BF}_{4}\right)\right)$, iodomethane $\left(\mathrm{CH}_{3} \mathrm{I}\right)$, sodium tetraphenylboron $\left(\mathrm{NaBPh}_{4}\right)$, methyltriphenylphosphonium iodide $\left(\left[\mathrm{PPh}_{3}-\right.\right.$ $\left.\mathrm{Me}]^{+} \mathrm{I}^{-}\right)$, sodium trifluoromethanesulfonate $\left(\mathrm{CF}_{3} \mathrm{SO}_{3} \mathrm{Na}\right)$ and sodium hexafluorophosphate $\left(\mathrm{NaPF}_{6}\right)$ were purchased from Sigma-Aldrich. THF was freshly distilled under nitrogen from $\mathrm{Na}$ /benzophenone. Hexane and toluene were purged with dry nitrogen before use.

Characterization. ${ }^{1} \mathrm{H},{ }^{31} \mathrm{P}$ and ${ }^{19} \mathrm{~F}$ NMR spectra were obtained by using a Bruker Avance $300\left({ }^{1} \mathrm{H}: 300 \mathrm{MHz} ;{ }^{31} \mathrm{P}: 120 \mathrm{MHz} ;{ }^{19} \mathrm{~F}\right.$ : $\left.282 \mathrm{MHz}\right)$ spectrometer at ambient temperature. Fourier transform infrared spectroscopy (FT-IR) spectra were recorded on a Bruker Tensor 27 spectrophotometer with a resolution of $4 \mathrm{~cm}^{-1}$ in attenuated total reflectance (ATR) mode. The THF/water solutions of $\mathrm{P}^{+} \mathrm{X}^{-}$were prepared by adding various amount of water into the solution of $\mathrm{P}^{+} \mathrm{X}^{-}(40 \mathrm{mg} / \mathrm{mL})$ in dry THF $(1.0 \mathrm{~mL})$. The spectra were quickly recorded after dripping the solutions on the ATR crystal. Low Field Nuclear Magnetic Resonance (LF-NMR) spectra were recorded on a VTMR20analyst NMR spectrometer (Ni-umag Electric Corporation, Suzhou, China) at $21 \mathrm{MHz}$. The magnet temperature was set at $35^{\circ} \mathrm{C}$ to ensure the constant rate of molecular motion for probing the system. $T_{2}$ was measured using the Carr-Purcell-Meiboom-Gill sequence (CPMG). ${ }^{1} T_{2}$ measurements were performed with a $\tau$-value (time between 90 pulse and 180 pulse) of $800 \mu \mathrm{s}$. Data were acquired as 8 scan repetitions. The repetition time between two succeeding scans was 5 seconds. The LF NMR relaxation curve was 
fitted to a multi-exponential curve with the MultiExp Inv Analysis software (Niumag Electric Corporation, Suzhou, China) using the inverse La-place transform algorithm. Surface tension of $\mathrm{P}^{+} \mathrm{X}^{-}$in water was tested on a DataPhysics DCAT 21 dynamic tensiometer instrument at $25^{\circ} \mathrm{C}$. Pure water was measured prior to the measurement of $\mathrm{P}^{+} \mathrm{X}^{-}$ colloidal solutions with varied concentrations. Zeta-potential and dynamic light scattering (DLS) of $\mathrm{P}^{+} \mathrm{X}^{-}$colloidal solutions were measured on a Malvern Zetasizer Nano ZS90 instrument at $25^{\circ} \mathrm{C}$. All the samples were freshly prepared and directly used for the measurement. Transmission electron microscopy (TEM) (Philips CM10 and FEI Talos S-FEG operated at an accelerating voltage of $60 \mathrm{kV}$ and $200 \mathrm{kV}$, respectively) and SEM (FEI Nova Nano SEM 450 operated at an accelerating voltage of $10 \mathrm{kV}$ ) were used to image the colloidal morphologies. TEM samples were prepared by placing a drop of solution onto a carbon-coated copper grid. The excess solution was removed using a piece of filter paper, and the grid was dried at ambient temperature for $24 \mathrm{~h}$. SEM samples were prepared by placing and drying a drop of solution onto a cleaned silicon wafer.

Preparation of colloids. The colloids of $\mathrm{P}^{+} \mathrm{X}^{-}$were prepared using THF as a cosolvent at $25{ }^{\circ} \mathrm{C}$. Certain amounts of $\mathrm{P}^{+} \mathrm{X}^{-}$were dissolved in $1.0 \mathrm{~mL}$ THF, yielding a clear yellow solution. To these THF solutions, $9.0 \mathrm{~mL}$ of deionized water was injected quickly. THF was removed by dialysis for $24 \mathrm{~h}$ against $2 \mathrm{~L}$ deionized water that was replaced three times. The cut-off molecular weight of cellulose membrane for the dialysis is ca. 14,000. Alternatively, THF was removed via $\mathrm{N}_{2}$ bubbling for $1 \mathrm{~h}$.

\section{Synthesis and characterization}

Synthesis of $\mathbf{P}(\mathbf{F p P})$. $\mathrm{P}(\mathrm{FpP})$ was synthesized via migration insertion polymerization (MIP) of $\mathrm{CpFe}(\mathrm{CO})_{2}\left(\mathrm{CH}_{2}\right)_{3} \mathrm{PPh}_{2}(\mathrm{FpP})$ in bulk at $70{ }^{\circ} \mathrm{C}$ according to our previous research. ${ }^{2}$ After polymerization, the crude products were first dissolved in a minimum amount of THF, and the solution was subsequently added dropwise into the degassed hexane to precipitate $\mathrm{P}(\mathrm{FpP})$. The precipitates were collected and dried under vacuum overnight at room temperature, Yield: $90 \%$. The NMR spectroscopy of the resulting $\mathrm{P}(\mathrm{FpP})$ was performed in DMSO-d $\mathrm{d}_{6}$ as shown in Fig. S1. The integral ratio of the $\mathrm{Cp}$ ring at the terminal group with those in the main chain is 1:6, indicating that the degree of polymerization (DP) is 7. GPC: $\mathrm{M}_{\mathrm{n}}=3343, \mathrm{M}_{\mathrm{w}}=3860$, PDI $=1.15 .{ }^{1} \mathrm{H} \mathrm{NMR}$ (DMSO-d 6 ): 7.4-7.1 ppm $\left(10 \mathrm{H}, \mathrm{C}_{6} H_{5}\right), 4.8-4.6 \mathrm{ppm}\left(5 \mathrm{H}, \mathrm{C}_{5} \mathrm{H}_{5}\right), 4.4-4.2 \mathrm{ppm}(5 \mathrm{H}$, $\left.\mathrm{C}_{5} H_{5}\right) .{ }^{31} \mathrm{P} \mathrm{NMR}\left(\mathrm{DMSO}_{\mathrm{d}}\right): 72.1,70.8 \mathrm{ppm}$ (coordinated phosphine in the main chain and in the terminal repeating unit), $-16.2 \mathrm{ppm}$ (phosphine end group).

Synthesis of $\mathbf{P}^{+} \mathbf{I}^{-}$via methylation of $\mathbf{P}(\mathbf{F p P})_{7}$. The obtained $\mathrm{P}(\mathrm{FpP})_{7}(1.0 \mathrm{~g}, 0.33$ mmol) powder was dissolved in THF $(2 \mathrm{~mL})$ and the excess amount of MeI $(10 \mathrm{~mL}$, $160 \mathrm{mmol}$ ) was added. After the mixture was stirred for 3 hours, unreacted MeI and THF were removed by rotary evaporator resulting in crude products. The desired product $\mathrm{P}^{+} \mathrm{I}^{-}$was collected via a cycle of solvation in THF $(1 \mathrm{~mL})$ and precipitation in hexane (200 mL). Yield: 92\%. ${ }^{1} \mathrm{H}$ NMR (DMSO-d 6$)$ : 7.8-7.6 ppm $\left(10 \mathrm{H}, \mathrm{C}_{6} H_{5}\right), 7.4-7.1 \mathrm{ppm}$ $\left(10 \mathrm{H}, \mathrm{C}_{6} H_{5}\right), 4.8-4.6 \mathrm{ppm}\left(5 \mathrm{H}, \mathrm{C}_{5} H_{5}\right), 4.4-4.2 \mathrm{ppm}\left(5 \mathrm{H}, \mathrm{C}_{5} \mathrm{H}_{5}\right) .{ }^{31} \mathrm{P} \mathrm{NMR}\left(\mathrm{DMSO}-\mathrm{d}_{6}\right)$ : 
70.7, $69.6 \mathrm{ppm}$ (coordinated phosphine), $24.4 \mathrm{ppm}$ (phosphonium).

As shown in Figure S1 and S2, the complete methylation is indicated by the disappearance of the ${ }^{31} \mathrm{P}$ NMR signal (P3) at $-16.2 \mathrm{ppm}$ (Figure S1), and the appearance of the peak at $24.4 \mathrm{ppm}$ (Figure S2) due to the phosphonium group. ${ }^{3}$ The formation of phosphonium cation shifts the ${ }^{1} \mathrm{H}$ NMR signal for the phenyl $(\mathrm{Ph})$ groups to 7.8-7.6 ppm (Figure S2). The splitting peaks of $\mathrm{Ph} 1$ and $\mathrm{Ph} 2$ are attributed to the $\mathrm{Ph}$ groups attached to the phosphonium cation and pendent to the main chains. The integral ratio of these two peaks is 1: 6, which is the same as the integral ratio for $\mathrm{Cp} 1: \mathrm{Cp} 2$ before (Figure S1) and after the methylation (Figure S2). It suggests that there is no degradation of the chain upon the methylation.

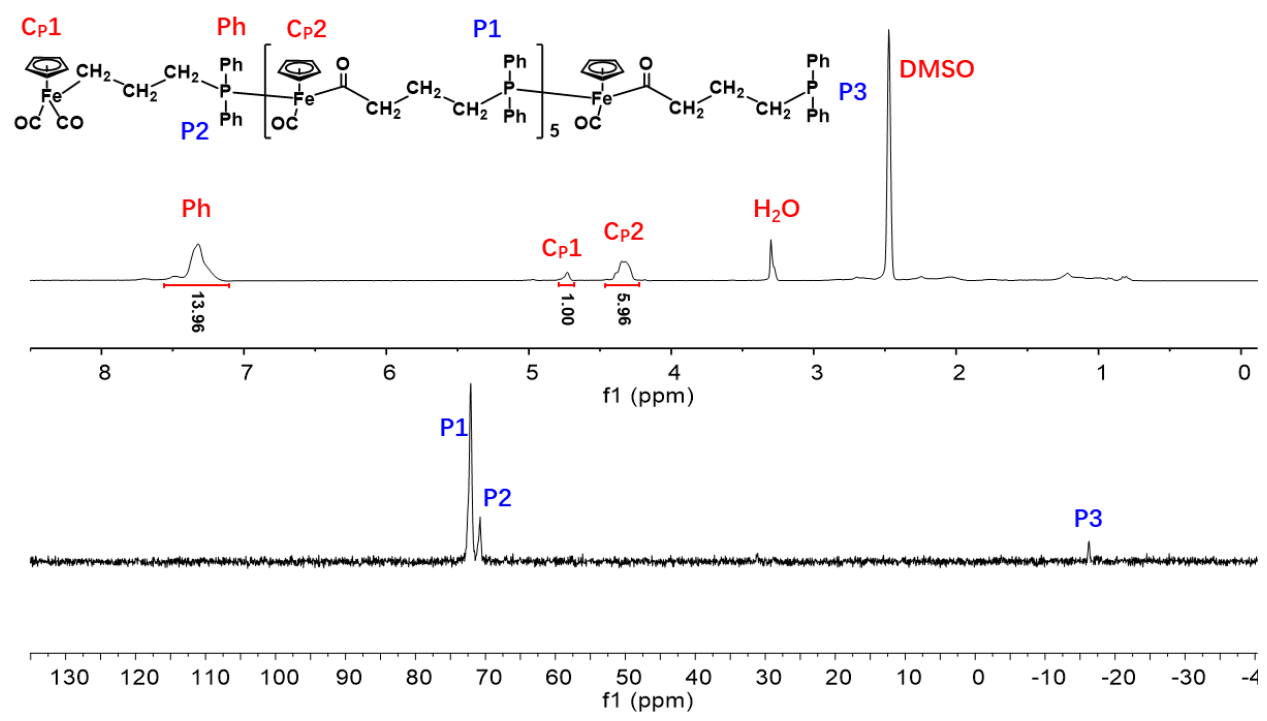

Figure S1. The chemical structure, ${ }^{1} \mathrm{H}$ (top) and ${ }^{31} \mathrm{P}$ (bottom) NMR (in DMSO-d 6 ) spectra for $\mathrm{P}(\mathrm{FpP})_{7}$.

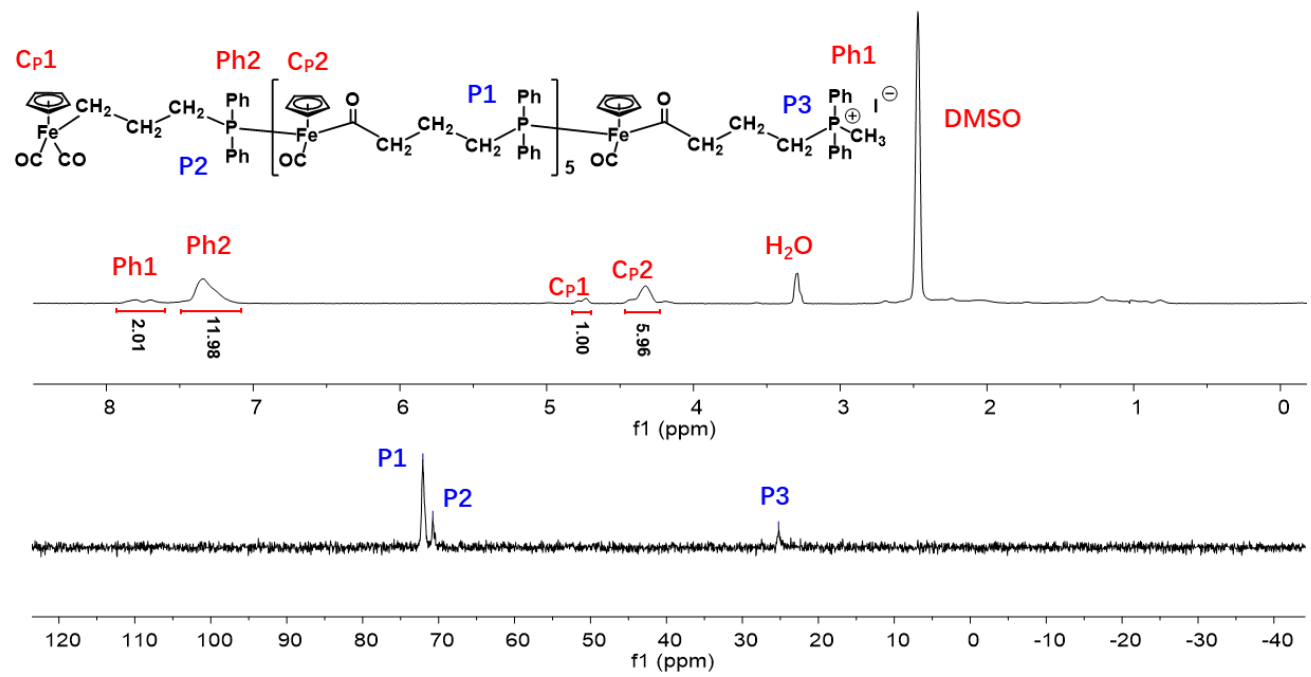

Figure S2. The chemical structure, ${ }^{1} \mathrm{H}$ (top) and ${ }^{31} \mathrm{P}$ (bottom) spectra (in DMSO-d $\mathrm{d}_{6}$ ) for $\mathrm{P}^{+} \mathrm{I}^{-}$produced after the methylation of $\mathrm{P}(\mathrm{FpP})_{7}$. 
Ion-exchange of $\mathrm{P}^{+} \mathbf{I}^{-}$. The ion-exchange of $\mathrm{P}^{+} \mathrm{I}^{-}$was realized by metathesis reactions. Typically, $300 \mathrm{mg}(0.10 \mathrm{mmol})$ of $\mathrm{P}^{+} \mathrm{I}^{-}$was dissolved in $2 \mathrm{~mL} \mathrm{THF}$, then a solution of excess amount of $\mathrm{NaBPh}_{4}(500 \mathrm{mg}, 1.50 \mathrm{mmol})$ in $\mathrm{MeOH}(5 \mathrm{~mL})$ was added. A yellow precipitate formed rapidly and the solution was subsequently stirred for $1 \mathrm{~h}$. The precipitate was collected after centrifuging and washing with excess amount of $\mathrm{MeOH}$ (30mL, 2 times) resulting in $\mathrm{P}^{+}\left[\mathrm{BPh}_{4}\right]^{-}$. All the other ion-exchange reactions for $\mathrm{P}^{+} \mathrm{X}^{-}$ $\left(\mathrm{X}^{-}=\left[\mathrm{CF}_{3} \mathrm{SO}_{3}\right]^{-},\left[\mathrm{PF}_{6}\right]^{-},\left[\mathrm{BF}_{4}\right]^{-}\right)$were performed in the same way and the resultant products were characterized by ${ }^{1} \mathrm{H},{ }^{31} \mathrm{P}$ and ${ }^{19} \mathrm{~F}$ NMR spectra. The NMR spectra for $\mathrm{P}^{+} \mathrm{X}^{-}$ products $\left(\mathrm{X}^{-}=\left[\mathrm{BPh}_{4}\right]^{-},\left[\mathrm{PF}_{6}\right]^{-},\left[\mathrm{BF}_{4}\right]^{-}\right.$, and $\left.\left[\mathrm{CF}_{3} \mathrm{SO}_{3}\right]^{-}\right)$are illustrated in Figure $\mathrm{S} 3, \mathrm{~S} 4$, S5, S6, respectively. $\mathrm{P}^{+}\left[\mathrm{BPh}_{4}\right]^{-}$(Figure S3): ${ }^{1} \mathrm{H}$ NMR (DMSO-d 6 ): 7.8-7.6 ppm (10H, $\left.\mathrm{C}_{6} H_{5}\right)$, 7.4-7.1 ppm (10H, $\left.\mathrm{C}_{6} H_{5}\right), 6.8-6.6 \mathrm{ppm}\left(20 \mathrm{H}, \mathrm{BC}_{6} H_{5}\right), 4.8-4.6 \mathrm{ppm}\left(5 \mathrm{H}, \mathrm{C}_{5} \mathrm{H}_{5}\right)$, 4.4-4.2 ppm (5H, $\left.\mathrm{C}_{5} \mathrm{H}_{5}\right) .{ }^{31} \mathrm{P}$ NMR (DMSO-d 6$): 72.1,70.8 \mathrm{ppm}$ (coordinated phosphine), $25.1 \mathrm{ppm}$ (phosphonium group). $\mathrm{P}^{+}\left[\mathrm{PF}_{6}\right]^{-}$(Figure $\left.\mathrm{S} 4\right):{ }^{1} \mathrm{H}$ NMR (DMSO- $\mathrm{d}_{6}$ ): 7.8-7.6 ppm (10H, $\left.\mathrm{C}_{6} H_{5}\right), 7.4-7.1 \mathrm{ppm}\left(10 \mathrm{H}, \mathrm{C}_{6} H_{5}\right), 4.8-4.6 \mathrm{ppm}\left(5 \mathrm{H}, \mathrm{C}_{5} \mathrm{H}_{5}\right), 4.4-4.2 \mathrm{ppm}(5 \mathrm{H}$, $\left.\mathrm{C}_{5} H_{5}\right) .{ }^{31} \mathrm{P}$ NMR (DMSO-d 6 ): 70.8, 69.8 ppm (coordinated phosphine), $24.1 \mathrm{ppm}$ (phosphonium group), -144.1 ppm (m, phosphorus in $\left.\left[\mathrm{PF}_{6}\right]^{-}\right) .{ }^{19} \mathrm{~F}$ NMR (DMSO-d 6 ): -69.1, $71.7 \mathrm{ppm}$ (fluorine in $\left.\left[\mathrm{PF}_{6}\right]^{-}\right) . \mathrm{P}^{+}\left[\mathrm{BF}_{4}\right]^{-}\left(\right.$Figure S5): ${ }^{1} \mathrm{H}$ NMR (DMSO-d $)$ ): 7.8-7.6 ppm $\left(10 \mathrm{H}, \mathrm{C}_{6} H_{5}\right), 7.4-7.1 \mathrm{ppm}\left(10 \mathrm{H}, \mathrm{C}_{6} H_{5}\right), 4.8-4.6 \mathrm{ppm}\left(5 \mathrm{H}, \mathrm{C}_{5} H_{5}\right), 4.4-4.2 \mathrm{ppm}(5 \mathrm{H}$, $\left.\mathrm{C}_{5} H_{5}\right) .{ }^{31} \mathrm{P}$ NMR (DMSO-d 6 ): 71.9, $70.8 \mathrm{ppm}$ (coordinated phosphine), $25.2 \mathrm{ppm}$ (phosphonium group). ${ }^{19} \mathrm{~F}$ NMR (DMSO-d $)$ ): $-148.5 \mathrm{ppm}$ (fluorine in $\left.\left[\mathrm{BF}_{4}\right]^{-}\right) .{ }^{4} \mathrm{P}^{+}\left[\mathrm{CF}_{3} \mathrm{SO}_{3}\right]^{-}$ (Figure S6): ${ }^{1} \mathrm{H}$ NMR (DMSO-d 6 ): 7.8-7.6 ppm $\left(10 \mathrm{H}, \mathrm{C}_{6} H_{5}\right), 7.4-7.1 \mathrm{ppm}\left(10 \mathrm{H}, \mathrm{C}_{6} \mathrm{H}_{5}\right)$, 4.8-4.6 ppm $\left(5 \mathrm{H}, \mathrm{C}_{5} H_{5}\right)$, 4.4-4.2 ppm (5H, $\left.\mathrm{C}_{5} H_{5}\right) .{ }^{31} \mathrm{P}$ NMR (DMSO-d 6 ): 72.0, 70.9 ppm (coordinated phosphine), $24.9 \mathrm{ppm}$ (phosphonium group). ${ }^{19} \mathrm{~F}$ NMR (DMSO-d 6 ): $-78.0 \mathrm{ppm}$ (fluorine in $\left.\left[\mathrm{CF}_{3} \mathrm{SO}_{3}\right]^{-}\right)^{5}$

The exchange of the $\mathrm{I}^{-}$anion by $\left[\mathrm{BPh}_{4}\right]^{-}$shifts the ${ }^{31} \mathrm{P}$ NMR signal for the phosphonium group from $24.4 \mathrm{ppm}$ (Figure S2) to $25.1 \mathrm{ppm}$ (Figure S3). In addition, ${ }^{1} \mathrm{H}$ NMR spectrum shows new signals at 6.8-6.6 ppm (Ph3) and a shoulder peak at $7.2 \mathrm{ppm}$ corresponding to the phenyl groups in $\left[\mathrm{BPh}_{4}\right]^{-}$. The integral ratio of $\mathrm{Ph} 1: \mathrm{Ph} 3=1: 2$ and $\mathrm{Ph} 1: \mathrm{Ph} 2=1: 6$ indicated that all the $\mathrm{I}^{-}$anion have been exchanged to $\left[\mathrm{BPh}_{4}\right]^{-}$and also the excess $\mathrm{NaBPh}_{4}$ salts have been removed. For the main chain structure of $\mathrm{P}^{+}\left[\mathrm{BPh}_{4}\right]^{-}$, the ${ }^{1} \mathrm{H}$ NMR integral ratio of $\mathrm{Cp} 1: \mathrm{Cp} 2$ is 1:6 confirming that the DP remains to be 7 after the ion-exchange reaction. The insolubility of the products in $\mathrm{THF} / \mathrm{MeOH}$ also indicates that the ion-exchange of $\mathrm{P}^{+} \mathrm{I}^{-}$is successfully, because the THF solution of $\mathrm{P}^{+} \mathrm{I}^{-}$ $(60 \mathrm{mg} / \mathrm{mL}, 1 \mathrm{~mL})$ cannot be precipitated by the addition of $5 \mathrm{~mL} \mathrm{MeOH}{ }^{3}$ As shown in Figure S4, S5, S6, the shifts of phosphonium group in ${ }^{31} \mathrm{P}$ NMR and the appearance of the resonance signals in ${ }^{19} \mathrm{~F}$ NMR indicates the occurrence of ion-exchange and $\mathrm{I}^{-}$is replaced by $\left[\mathrm{CF}_{3} \mathrm{SO}_{3}\right]^{-},\left[\mathrm{PF}_{6}\right]^{-},\left[\mathrm{BF}_{4}\right]^{-}$, respectively. The integral ratio of $\mathrm{Cp} 1: \mathrm{Cp} 2$ and $\mathrm{Ph} 1: \mathrm{Ph} 2$ remains to be 1:6 confirming that the chain with DP of 7 is not degraded. 



Figure S3. The chemical structure, ${ }^{1} \mathrm{H}$ (top) and ${ }^{31} \mathrm{P}$ (bottom) NMR spectra (DMSO- $\mathrm{d}_{6}$ ) for $\mathrm{P}^{+}\left[\mathrm{Ph}_{4} \mathrm{~B}\right]^{-}$.



Figure S4. The chemical structure, ${ }^{1} \mathrm{H}$ (top), ${ }^{31} \mathrm{P}$ (middle) and ${ }^{19} \mathrm{~F}$ (bottom) NMR spectra $\left(\mathrm{DMSO}^{\left.-\mathrm{d}_{6}\right)}\right.$ for $\mathrm{P}^{+}\left[\mathrm{PF}_{6}\right]^{-}$. 




Figure S5. The chemical structure, ${ }^{1} \mathrm{H}$ (top), ${ }^{31} \mathrm{P}$ (middle) and ${ }^{19} \mathrm{~F}$ (bottom) NMR spectra $\left(\mathrm{DMSO}_{-} \mathrm{d}_{6}\right)$ for $\mathrm{P}^{+}\left[\mathrm{BF}_{4}\right]^{-}$.
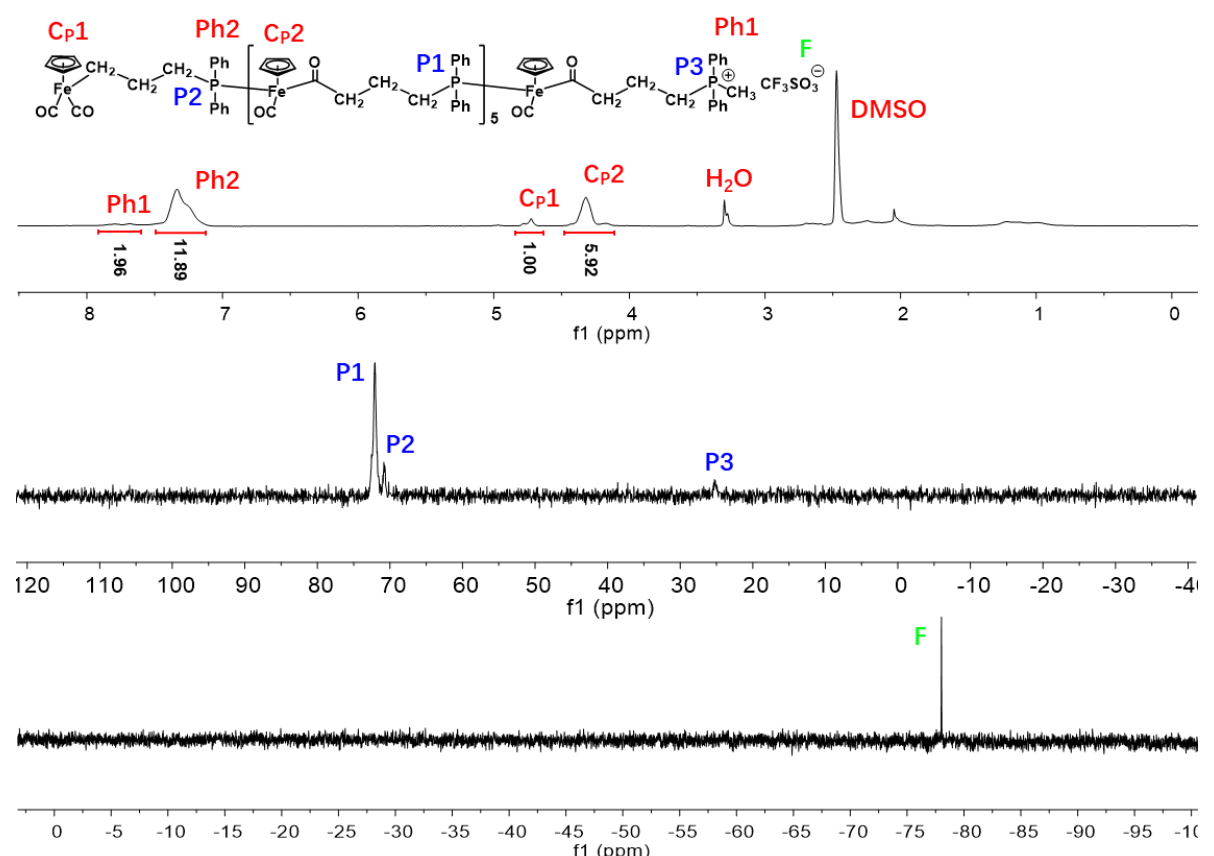

Figure S6. The chemical structure, ${ }^{1} \mathrm{H}$ (top), ${ }^{31} \mathrm{P}$ (middle) and ${ }^{19} \mathrm{~F}$ (bottom) NMR spectra $\left(\mathrm{DMSO}_{-} \mathrm{d}_{6}\right)$ for $\mathrm{P}^{+}\left[\mathrm{CF}_{3} \mathrm{SO}_{3}\right]^{-}$. 


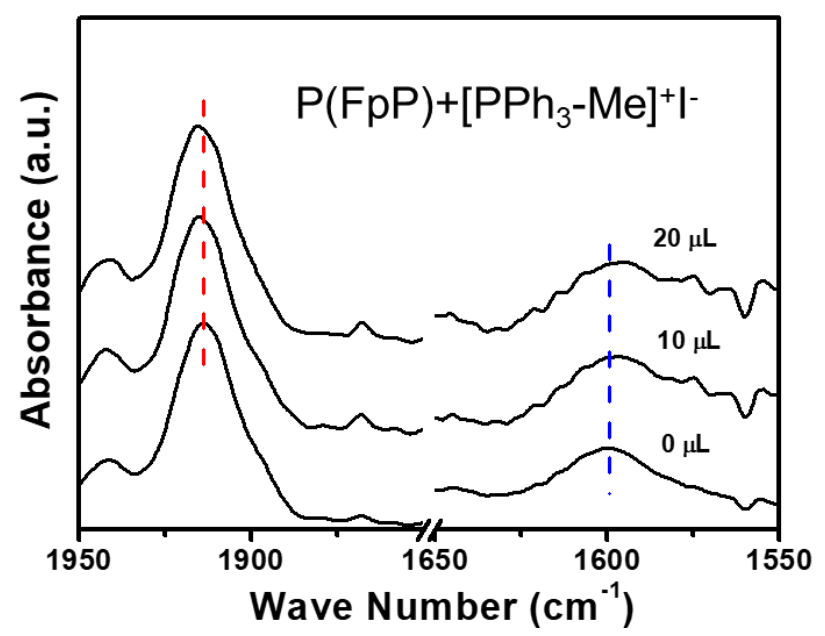

Figure S7. FT-IR absorptions of the $\mathrm{CO}$ groups for the solutions of $\mathrm{P}(\mathrm{FpP})_{7} /\left[(\mathrm{Ph})_{3} \mathrm{PMe}\right]^{+} \mathrm{I}^{-}($molar ratio $=1 / 1)$ in THF $\left(1 \mathrm{~mL}, 6.7 \times 10^{-3} \mathrm{mM}\right.$ for the two components. $40 \mathrm{mg} / \mathrm{mL}$ for macromolecules and $5.4 \mathrm{mg} / \mathrm{mL}$ for $\left.\left[(\mathrm{Ph})_{3} \mathrm{PMe}\right]^{+} \mathrm{I}^{-}\right)$in the presence of various amounts of water $(0-20 \mu \mathrm{L})$. 

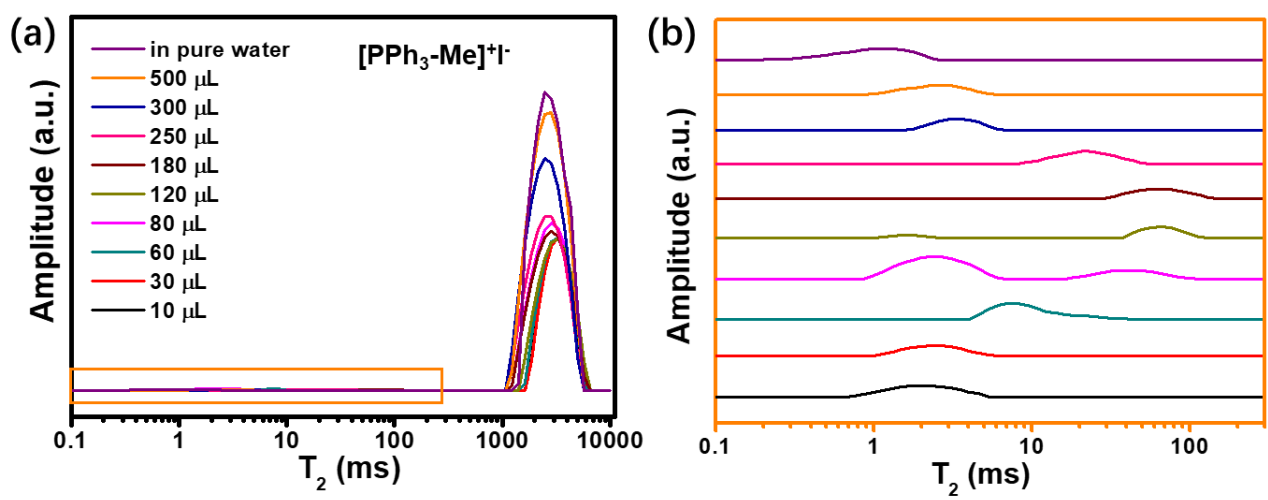

Figure S8. LF NMR relaxometry analysis of water perturbated by $\left[(\mathrm{Ph})_{3} \mathrm{PMe}\right]^{+} \mathrm{I}^{-}$. (a) LF-NMR spectra for $\left[(\mathrm{Ph})_{3} \mathrm{PMe}^{+} \mathrm{I}^{-}\left(2.7 \mathrm{mg}, 6.7 \times 10^{-6} \mathrm{~mol}\right)\right.$ in THF $(500 \mu \mathrm{L})$ with various amounts of water $(0-500 \mu \mathrm{L})$. (b) The enlarged view of the spectra within the organ square in (a).

As shown in Figure S8, when a small amount of water $(10 \mu \mathrm{L}-60 \mu \mathrm{L})$ was added, the salt is ionized and start to convert the ion pair from direct contacted to closely contacted. As the amount of water increases, the $T_{2}$ due to the bound water increases probably due to the overlapped $T_{2}{ }^{W}$ and $T_{2}{ }^{S}$. When the added water is $80-180 \mu \mathrm{L}$, the amount of water ordered by the closed contacted ion pair becomes large, which exerts a strong H-Bond cooperativity to lower the mobility of water, so the $T_{2}{ }^{W}$ becomes obvious. Further addition of water, the increase in the ionization degree start to separate the closely contacted ion pair to loosely contacted ion pair, which lowers the order of water between the ion pair. The $T_{2}{ }^{S}$ is averaged with $T_{2}{ }^{W}$ and shift to lower relaxation time as the water content increases. 

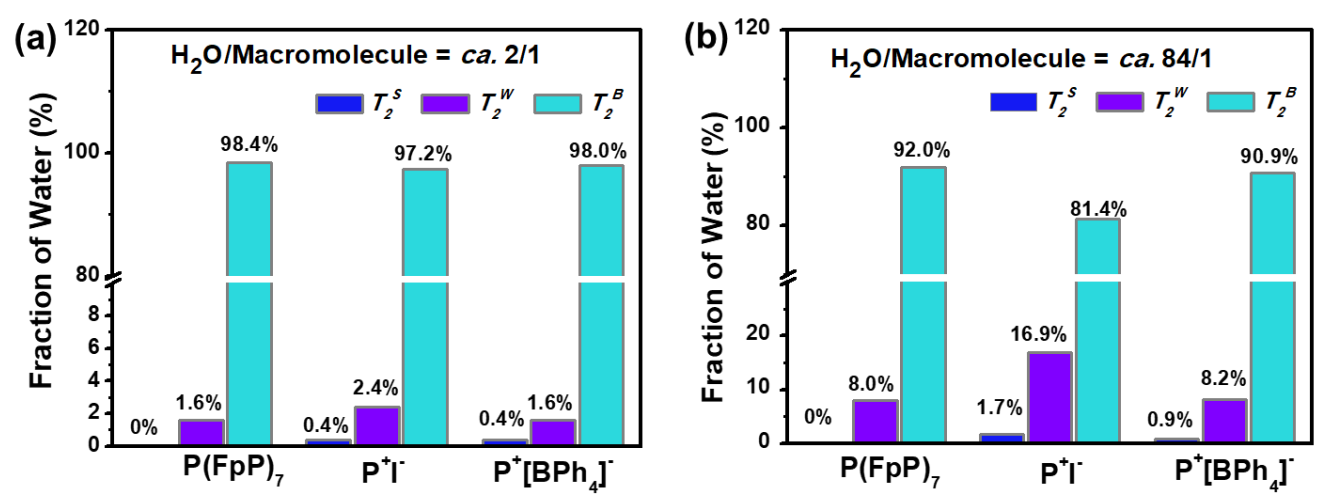

Figure S9. The fraction of water with relaxation time of $T_{2}{ }^{B}, T_{2}{ }^{W}, T_{2}{ }^{S}$ for the solution of $\mathrm{P}(\mathrm{FpP})_{7}, \mathrm{P}^{+} \mathrm{I}^{-}$and $\mathrm{P}^{+}\left[\mathrm{BPh}_{4}\right]^{-}$in THF with (a) $0.5 \mu \mathrm{L}\left(\mathrm{H}_{2} \mathrm{O} /\right.$ Macromolecules $\left.=c a .2 / 1\right)$ and (b) $20 \mu \mathrm{L}\left(\mathrm{H}_{2} \mathrm{O} /\right.$ Macromolecules $=c a$. 84/1) water. 

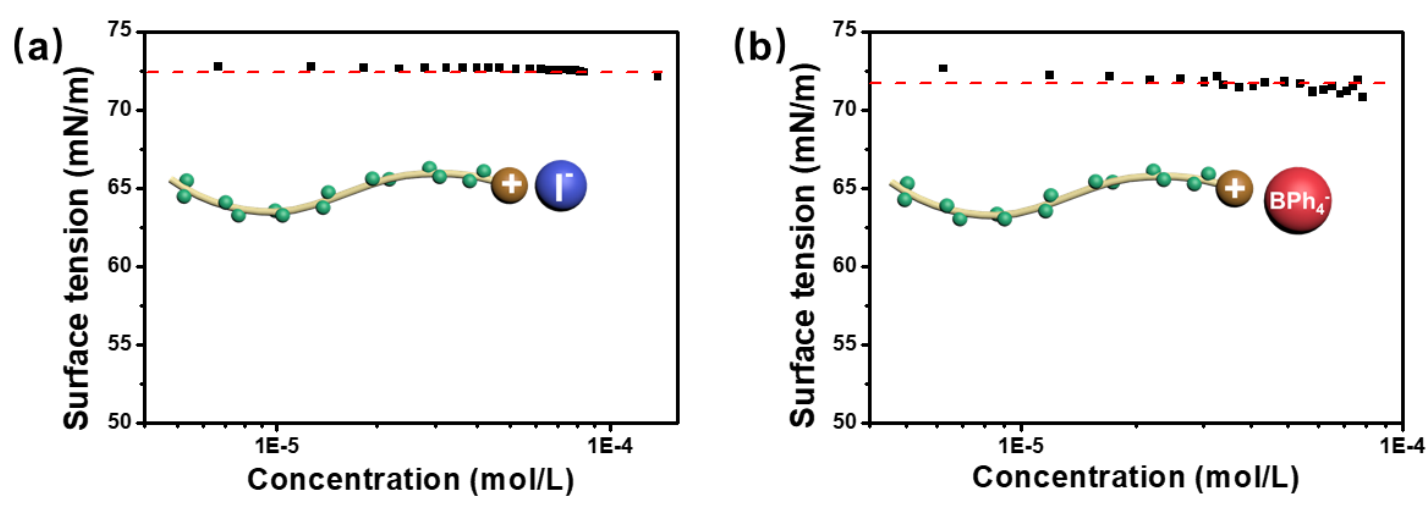

Figure S10. Surface tension of (a) $\mathrm{P}^{+} \mathrm{I}^{-}$, and (b) $\mathrm{P}^{+}\left[\mathrm{Ph}_{4} \mathrm{~B}\right]^{-}$in water as a function of concentration. $\mathrm{P}^{+} \mathrm{I}^{-}$and $\mathrm{P}^{+}\left[\mathrm{Ph}_{4} \mathrm{~B}\right]^{-}$, like $\mathrm{P}(\mathrm{FpP})_{7}$, are not soluble in water. ${ }^{6}$ Therefore, the colloidal solutions in water was first prepared and the resultant solutions $(0.1 \mathrm{mg} / \mathrm{mL})$ were diluted by adding water and the surface tensions were subsequently measured. The surface tension for the solutions at all concentrations is $c a .72 .30 \mathrm{mN} / \mathrm{m}$, which is almost the same as the value for pure water $\left(72.75 \mathrm{mN} / \mathrm{m}\right.$ at $\left.22{ }^{\circ} \mathrm{C}\right)$. The absence of critical micelle concentration $(\mathrm{CMC})$ suggests that $\mathrm{P}^{+} \mathrm{I}^{-}$and $\mathrm{P}^{+}\left[\mathrm{Ph}_{4} \mathrm{~B}\right]^{-}$cannot be classified as classical amphiphiles. ${ }^{7}$ 
Table S1. Aqueous self-Assembly of $\mathrm{P}^{+} \mathrm{I}^{-}$at varied concentrations

\begin{tabular}{cccc}
\hline $\begin{array}{c}\text { Concentration } \\
(\mathrm{mg} / \mathrm{mL})\end{array}$ & $\begin{array}{c}\text { Zeta-potential } \\
(\mathrm{mv})\end{array}$ & $\mathrm{D}_{\mathrm{h}}(\mathrm{nm})$ & PDI \\
\hline 0.1 & +33.4 & 162.8 & 0.48 \\
0.5 & +35.8 & 129.2 & 0.37 \\
1.0 & +48.3 & 93.4 & 0.17 \\
\hline
\end{tabular}
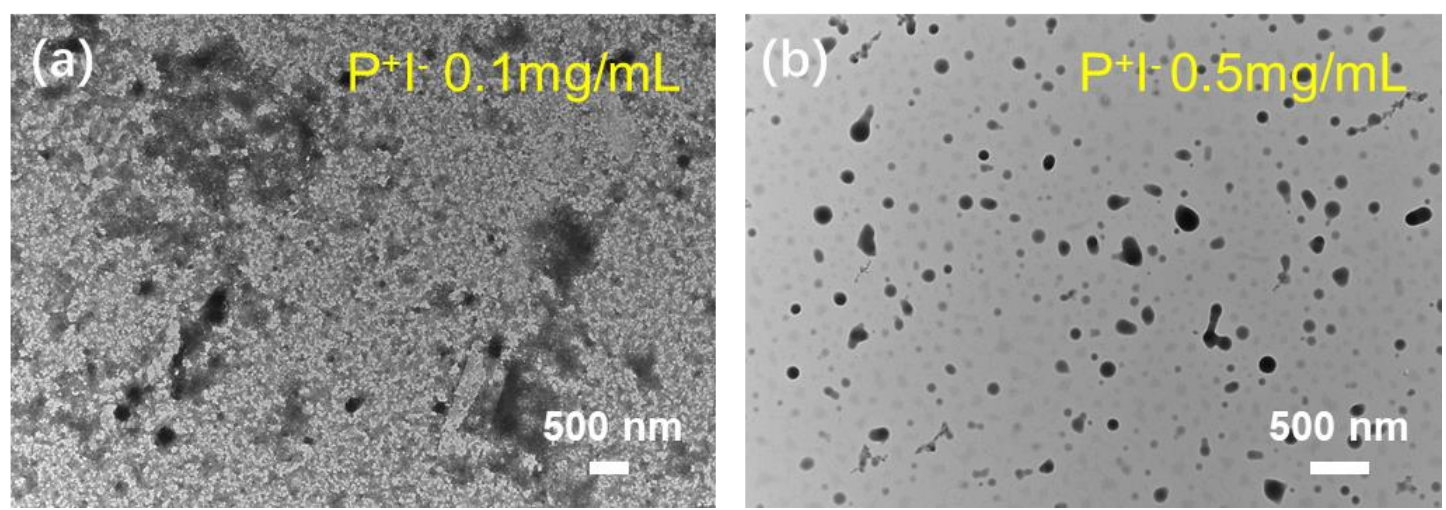

Figure S11. The TEM images for $\mathrm{P}^{+} \mathrm{I}^{-}$colloids with the concentration of (a) $0.1 \mathrm{mg} / \mathrm{mL}$ and (b) $0.5 \mathrm{mg} / \mathrm{mL}$. The THF in colloids are removed via a dialysis process. 

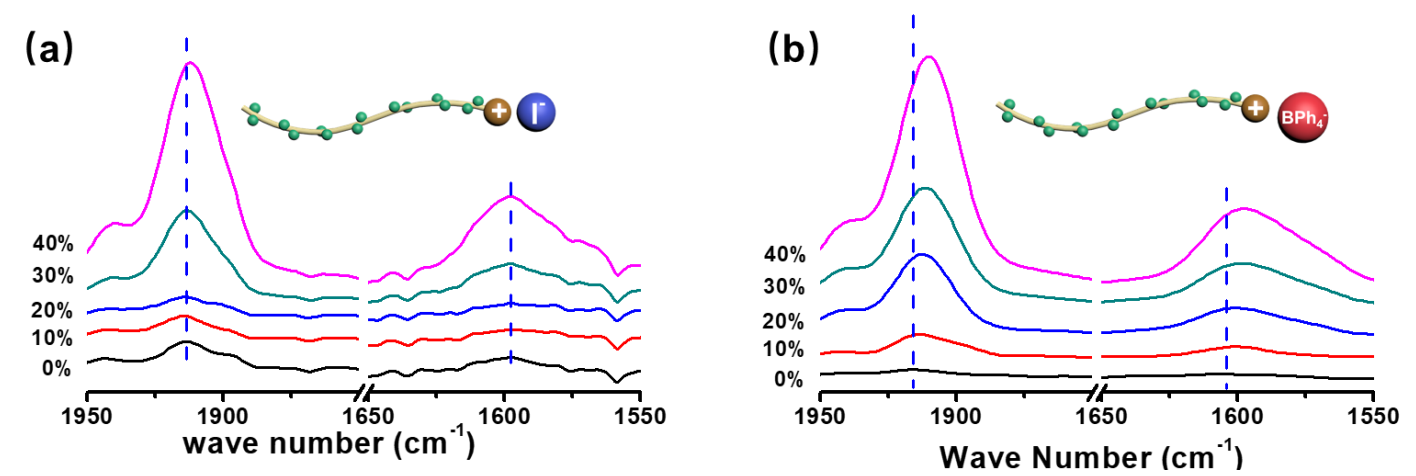

Figure S12. FT-IR spectra of CO absorptions for (a) $\mathrm{P}^{+} \mathrm{I}^{-}$and (b) $\mathrm{P}^{+}\left[\mathrm{BPh}_{4}\right]^{-}$in THF (1 $\mathrm{mL}, 20 \mathrm{mg} / \mathrm{mL}$ ) with $0 \%, 10 \%, 20 \%, 30 \%, 40 \%$ (vol) $\mathrm{D}_{2} \mathrm{O}$ added.

$\mathrm{P}^{+} \mathrm{I}^{-}$and $\mathrm{P}^{+}\left[\mathrm{BPh}_{4}\right]^{-}$starts to aggregates obviously at $30 \mathrm{vol} \%$ and $10-20 \mathrm{vol} \%$ of water. respectively, which is indicated by the enhanced IR absorption due to the presence of an aggregation-induced local electric field. ${ }^{8-10}$ No red-shift of the absorption upon the addition of water suggests the absence of $\mathrm{WCI}$ for $\mathrm{P}^{+} \mathrm{I}^{-}$before and after the aggregation. However, the red-shift of the absorption becomes much obvious after the aggregation. It is $7 \mathrm{~cm}^{-1}$ for the terminal $\mathrm{CO}$ groups and $5 \mathrm{~cm}^{-1}$ for the acyl CO groups when the water content is $40 \%$. It suggests that the $\mathrm{CO}$ groups remain hydrated via WCI after the aggregation.
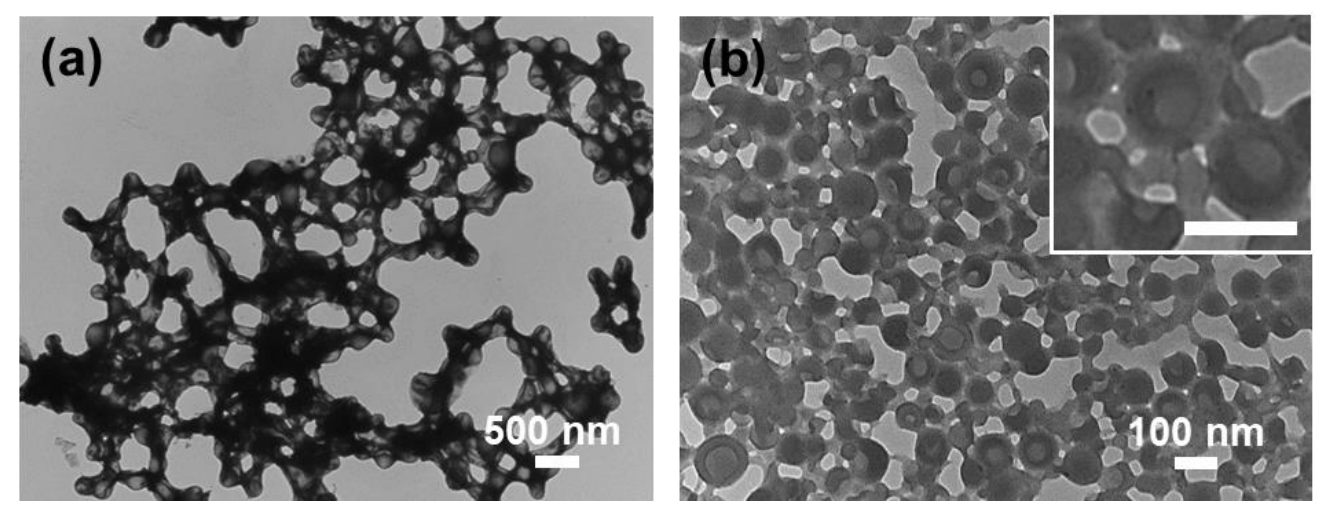

Figure S13. The TEM images for $\mathrm{P}^{+}\left[\mathrm{BPh}_{4}\right]^{-}$vesicles in water after removal of THF via (a) a $\mathrm{N}_{2}$ bubbling process and (b) a dialysis process. The concentrations of the colloids are in $0.1 \mathrm{mg} / \mathrm{mL}$, the scare bar for the insect in (b) is $100 \mathrm{~nm}$. 


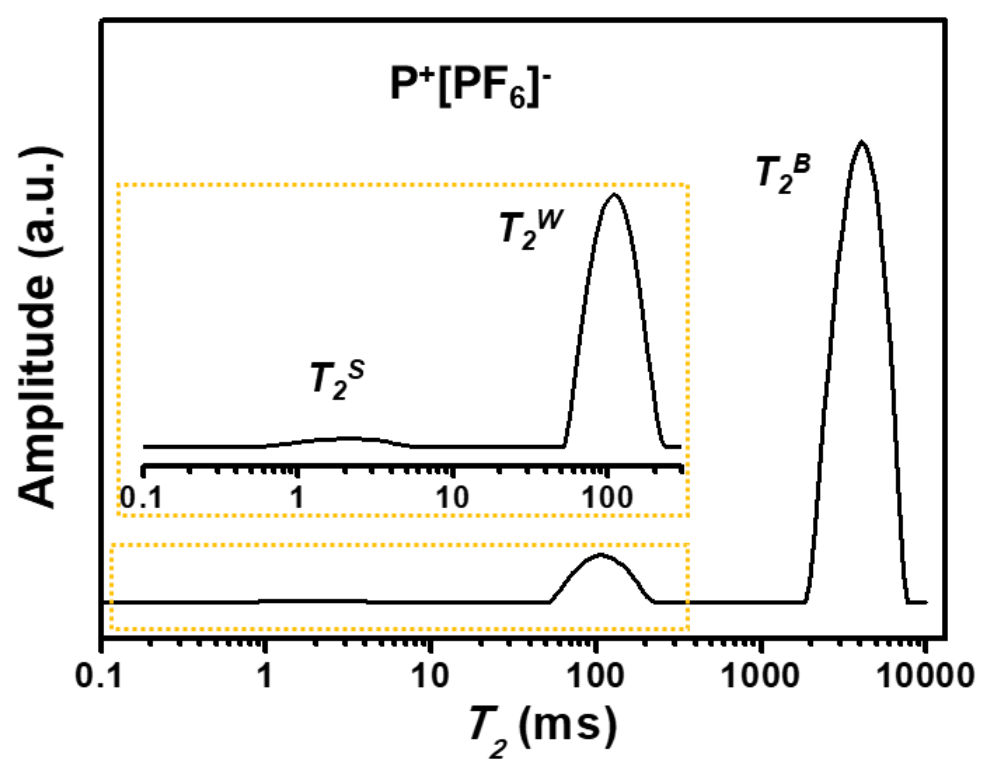

Figure S14. LF NMR spectrum of $\mathrm{P}^{+}\left[\mathrm{PF}_{6}\right]^{-}$in THF $(40 \mathrm{mg} / \mathrm{mL}, 1 \mathrm{~mL})$ in the presence of $20 \mu \mathrm{L}$ water. The molar ratio of water/macromolecules is $84 / 1$. The $T_{2}{ }^{S}, T_{2}{ }^{W}$ and $T_{2}{ }^{B}$ represent the electrostatically bound water, water bound to $\mathrm{CO}$ groups and bulk water, respectively. The fractions of these water molecules with $T_{2}{ }^{S}, T_{2}{ }^{W}$ and $T_{2}{ }^{B}$ are $0.5 \%, 9.5 \%$ and $90.0 \%$, respectively, which are similar with those for $\mathrm{P}^{+}\left[\mathrm{BPh}_{4}\right]^{-}$. 


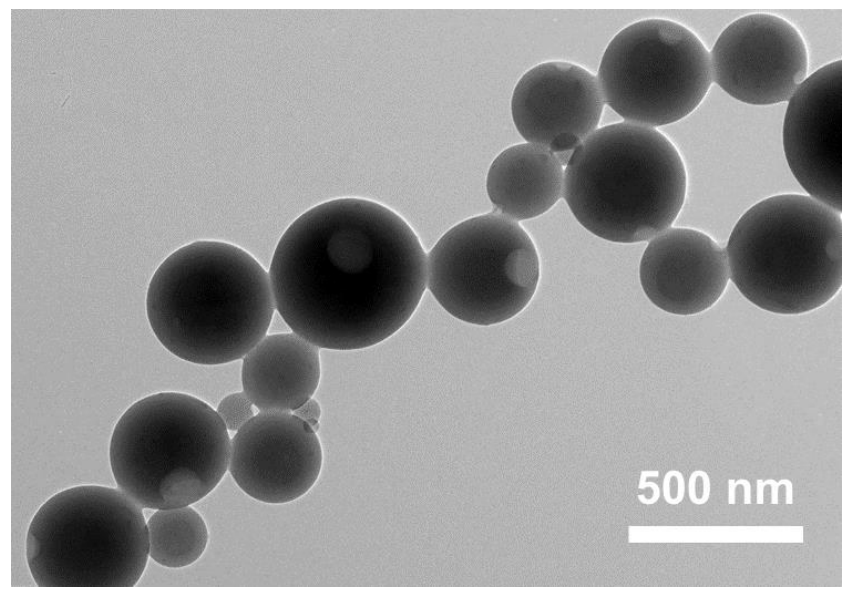

Figure S15. TEM image for the $\mathrm{P}^{+}\left[\mathrm{PF}_{6}\right]^{-}$colloids in water by removal of THF via a dialysis process. The concentration of colloid is $0.1 \mathrm{mg} / \mathrm{mL}$. The hollow structure is confirmed by SEM image (Figure 5d).

\section{References}

1. Carr, H. Y.; Purcell, E. M., Effects of diffusion on free precession in nuclear magnetic resonance experiments. Phys. Rev. 1954, 94 (3), 630.

2. Wang, X.; Cao, K.; Liu, Y.; Tsang, B.; Liew, S., Migration insertion polymerization (MIP) of cyclopentadienyldicarbonyldiphenylphosphinopropyliron (FpP): a new concept for main chain metalcontaining polymers (MCPs). J. Am. Chem. Soc. 2013, 135 (9), 3399-3402.

3. He, X.; Hsiao, M.-S.; Boott, C. E.; Harniman, R. L.; Nazemi, A.; Li, X.; Winnik, M. A.; Manners, I., Two-dimensional assemblies from crystallizable homopolymers with charged termini. Nat. Mater. 2017, $16(4), 481$.

4. Honeychuck, R. V.; Hersh, W. H., Observation of anion spinning in the dynamic phosphorus-31 NMR spectra of fluorine-bridged SbF6-, BF4-, and PF6-adducts of R3P (CO) 3 (NO) W+. Implications for barriers to ionization and the formation of ion pairs and free ions in methylene chloride and hexane solution. J. Am. Chem. Soc. 1989, 111 (16), 6056-6070.

5. Hollis, T. K.; Robinson, N.; Bosnich, B., Homogeneous catalysis. Titanium complex [Ti (Cp) 2 (CF3SO3) 2] and zirconium complex [ $\mathrm{Zr}(\mathrm{Cp}) 2$ (CF3SO3) 2THF], efficient catalysts for the Diels-Alder reaction. Organometallics 1992, 11 (8), 2745-2748.

6. Cao, K.; Murshid, N.; Li, L.; Lopez, A.; Tam, K. C.; Wang, X., Hydration of Hydrophobic IronCarbonyl Homopolymers via Water-Carbonyl Interaction (WCI): Creation of Uniform Organometallic Aqueous Vesicles with Exceptionally High Encapsulation Capacity. Macromolecules 2015, 48 (21), 7968-7977.

7. Elworthy, P. H.; Mysels, K. J., The surface tension of sodium dodecylsulfate solutions and the phase separation model of micelle formation. J. Colloid Interface Sci. 1966, 21 (3), 331-347.

8. Anderson, M. S., Enhanced infrared absorption with dielectric nanoparticles. Appl. Phys. Lett. 2003, 83 (14), 2964-2966. 
9. Murshid, N.; Wang, X., Iron-Carbonyl Aqueous Vesicles (MCsomes) by Hydration of [Fe (CO) \{CO (CH2) $5 \mathrm{CH} 3\}(\mathrm{Cp})(\mathrm{PPh} 3)](\mathrm{FpC} 6)$ : Highly Integrated Colloids with Aggregation-Induced Self-Enhanced IR Absorption (AI-SEIRA). Chem. Eur. J. 2015, 21 (52), 19223-19230.

10. Murshid, N.; Wang, X., Hydrophobic Effect of Alkyl Groups Stabilizing Self-Assembled Colloids in Water. J. Phys. Chem. B 2017, 121 (25), 6280-6285. 